\title{
The British Colony in Paris, 1792-93
}

THE French Revolution drew to Paris enthusiasts from all parts 1 of the world, bat as far as I can judge the British visitors outnumbered those of any other nationality, and that revolution being regarded by them as a French 1688, they were the most prominent in their demonstrations of sympathy. It is true that on Cloots's memorable depatation of 19 June 1790 only four British subjectsDr. Price and companions quite unknown to fame, named Procter, Townsend, and Brown ${ }^{1}$ - can be positively traced; bat seventeen months later, when the monarchy had disappeared, and when war between England and France was becoming imminent, those British visitors whom the excesses of the Rovolution had not frightened away had a demonstration all to themselves.

On Sunday, 18 Nor. 1792, they assembled at a dinner at White's Hotel, or the Hottel d'Angleterre, 8 Passage des Petits-Pères, to celebrate the victories of the French arms. The Passage des Petits-Pères was constracted in 1779 . It led from the Rue NotreDame des Victoires to the monastery of the Petits Pères, or Austinfriars. Starting from south to north, it turned midway at a right angle from west to east. The houses facing the east backed on the Rue Vivienne, while those facing the south had the monastery grounds at the back. That part of the Passage running from south to north is now a portion of the Rue de la Banque, for in 1844 the opening was continued northwards to the Bourse and received that name. White's Hotel ras situated in a court, and the site is now occupied by the Galerie des Petits-Pères, which leads from 5 Rue de la Banque to the Rue Vivienne. The adjoining bouse was called the Hôtel des Etats-Unis. Both hotels were probably patronised by British visitors, and Americans also stayed at White's, for in October 1793 Livingstone and Gregory dated therefrom a letter to Robespierre offering to supply American flour. The house had then taken the name of Hôtel de Philadelphie." We shall presently see that the committee appointed at this dinner numbered fifty, and assuming that another fifty were present, it is not likely that the two

' Probably a mechanician, and aftermards a teacher of languages, in Paris.

- Papiers troutes ches Robespierre. 
hotels together could accommodate more than a handred guests. However this may be, the toasts included 'the speedy abolition of hereditary titles and feudal distinctions in England,' 'the coming convention of Great Britain and Ireland ' (this forestalled the Act of (Enion), 'the lady defenders of the Rerolation, particularly Mrs. Charlotte Smith, Miss Williams, and Mrs. Barbauld,' ' Paine and the new way of making good books known by a royal proclamation and King's Bench prosecution,' ' the English patriots Priestler, Fox, Sheridan, Christie, Cooper, Tooke, and Ifackintosh.' But what interests us more than the toasts was the adoption of an address to the Convention. It was in these terms: ${ }^{3}$

\section{Address of the English, Scotch, and Irish resident and domiciled in Paris.}

Citizen Legislators, - The British and Irish citizens now in Paris, animated by the sentiment of liberty which your principles have imparted to the French repnblic, assembled on Sunday, 18 Norember, to celebrate the brilliant successes of your arms, and were unanimously of opinion that it was their duty to offer to the representatires of so great a nation the tribute of their congratulations on erents which essentially interest all peoples who aspire to be free. Broceive, then, citizen legislators, this pure and fraternsl homage of men who have ever applauded the sacred principles upon which you hare sworn to base the new government which you are about to give to your country. Hitherto wars lare been undertaken only to satiate the rilest passions; they have consequently been conducted only by the most iniquitous methods. You hare taken up arms solely to inake reason and trath triomph. It donbtless appertained to the French nation to enfranchise Europe, and we rejoice to see it falblling its great destinies. Let us hope that the victorious troops of liberty will lay down their arms only when there are no more tyrants or slaves. Of all these pretended governments, works of the fraud of priests and coslesced tyrants, there will soon remain only a shsmefal memory. Peoples enlightened by your ezample will blush to hare bowed servile heads so long onder a yoke debasing for human nature.

Our good wishes, citizen legislators, render us impatient to see tho happy moment of this great clange, in the hope that it will no sooner arrire than we shall see the formation of a close union between the French republic and the English, Scotch, and Irish nstions, a union which cannot fail to ensure entire Earope the enjoyment of the rights of man and establish on the firmest bases unirersal peace. We are not the only men animated by this sentiment. We doubt not that they would

- Archites Nationales, C. 242. The address, spperently in Stone's writing, fills a pega and a half of a sheet of toolscap, the ink nor mach faded. The signatures from Treddell to Beyment ocenpy in two colmonns the reat of the second page, the remaining names being written on the other half of the shoet in a single column, and one president and secretery signing at the top of a second colnmn. Stone and O'Reilly, it will be obserred, inedvertently sign trice orer. The signatures are nor publighed for the first time. The rersion of the address giren in the sfoniterr contains some slight inscecuracies.

POL. SIII.- -No. LII. 
be also manifested by the grest majority of our connirymen if public opinion were consulted, as it ought to be, in a national convention.

As for us, who are at present making Paris our residence, we gladly embrace this opportunity of declaring that in the whole course of the Berolution, and notwithstanding the abrupt departare of our ambassedor, we have constantly experienced on the part of the French nation sentiments of the frankest cordiality and sincerest friendship.

Paris, 24 Nov. 1792, first jear of the Fronch republic. Signed by us, members of the committee nominated for that purpose.

Francis Tweddell.

Matthew Bellewes.

John Frost.

Riohard Joyce.

Joseph Green.

J. Skill.

J. Uaher Quaterman.

David Gibson.

Thomas Armfield.

Edward Fitzgerald.

William Duckett.

J. O'Neill.

Edmard Ferris.

B. Murray.

J. H. Stone, President.

Joseph Webb.

William Newton.

J. Tickell.

Harrold Mowatt.

Pearce Iower.

Bernald MacBheehy.

Jeremie Curtayn.

William Choppin.

William Wardell.

N. Madgett.

James Gamble.

(Wait for the President's reply.)
Thos. MacDermott.

William Rickette.

Robert Rayment.

William Francis Jackson.

Robert Merry.

Robert May O'Reilly.

J. E. Macdonnel.

William Watts.

Thomas Marshall.

John Oswald.

John Walker, sen.

Thomas Potier.

I. Mrsquerier.

R. Smyth.

N. Hickson.

T. J. Grostinesu.

Stephen Sayre.

Henry Sheares.

John Sheares.

Bose.

John Bradley.

IVilliam Maxwell.

B. Bulmer.

Cesar Colclough.

J. H. Stone, President.

Robert MI. O'Reilly, Secretary.

The address was not presented till the 28th. This delay may be attributed to a resolution to wait for the arrival of Joel Barlow and John Frost," who on 9 Nor. had been deputed by the London Society for the Diffusion of Constitational Information to take over an address. They wrote on the 27th from White's Hotel to the president of the Convention, asking that a day might be arranged for receiving them. The following day at noon was fixed. Both addresses Fere accordingly presented on the 28th. First came Stone and the forty-nine other members of the White's Hotel committee. Thomas Paine had dorbtless been at the meeting, for we 
have seen that his health was drank, but himself sitting in the Convention he obviously could not sign an address to that body.

The address from London was doabtless read by Barlor. The version published by the Moniteur (29 Nov. 1792) contains numerous inaccuracies, bat without detailing these it is enough to say that the society had sent a thonsand pairs of shoes for the French soldiers, and promised to send a thousand more weekly for at least six weeks.

Before seeing what became of the memorialists let us note the history of these gatherings at White's. The chief authority is Captain George MIonro, who, on the rithdrawal of the British embassy in August 1792, had been left in Paris to send information to his government. 'I have sent a rery good man,' wrote Bland Burges to Lord Auckland on 17 Aug. 1792, 'to look about him in Paris after they [Lord Gower and Lindsay] $\operatorname{come}$ away, and who will let us know from day to day what passes.'s It was evidently part of Monro's daty to keep an eye on British visitors, and, if this made him virtually a spy, it was natural that the English authorities should desire to be posted up in the movements of men, some of whom, as he wrote, were 'ready to put anything in execution that would injure their country, let the measure be never so desperate.' The better, therefore, to discharge his daty, Monro actually went to lodge at White's. He was doubtless present at the dinner of 28 Nov., and he forwarded to the Foreign Office a copy of the address to the Convention, but without the signatures. On $17 \mathrm{Dec}$. he reported that the 'party of conspirators' had 'formed themsel res into a society,' and $\pi e$ know from the Moniteur ( $5 \mathrm{r} .58$ ) that on 5 Jan. they gave formal notice of the formation of the Society of Friends of the Rights of Man, which was to meet twice a week. The first meeting was held on 16 Dec., when the president of the Mail section delivered a speech, a copy of which was forwarded to the Foreign Office by Monro. Merry was president, and a Dr. Edwards had arrived to join Maxwell; but Paine was then staying in the provinces, 'ill or pretending to be so,' Stone had returned to England, and Frost had removed to cheaper lodgings. On 27 Dec. Mionro reports that many of the party had become friends of royalty, though there were still many " who would stand at nothing to ruin their country.' Four days later he describes the remnant as ' beneath the notice of any one, struggling for consequence among themselves, jealous of one another, differing in opinion, and even insignificant in a body.' With ferr exceptions they were 'heartily tired of politics and addresses. Tom Paine's fate [outlamry] and the unanimity of the English has staggered the boldest of them, and they are now drindling into nothing.' On 11 Jan. 1793 ancther address ras advocated by Paine and Nerry, bat was so 
warmly opposed by Frost and Ifaclonald (Macdonnel) that 'the dispnte nearly ended in blows. I cannot tell how it ended, as things are kept very secret.' $G$ Henry Pedhead Yorke tells us the particulars. The address invited the Convention to liberate ensiaved England. He opposed it, and 'we carried it' - that is to say, the address was rejected- 'by a majority of one.' It was, however, again brought forward, whereupon Yorke and Johnson drew up a remonstrance and seceded. This second address was presented to the Conrention on 22 Jan., but I hare not found it in the national archives.

A London bookseller named Thompson arrived about this time, and denounced Monro as a spy who 'had joined the society to find out what they were doing." Monro's despatches cease in February 1793, and he then retarned to England, his place being taken by one Somere, who, until the end of F'ebruary, wrote letters to Monro and Bland Burges, using mercantile terms to disguise political news. Monro is said, indeed, to have been arrested, and to have owed his release to Paine, ${ }^{7}$ but his apprehension was not ordered by the committee of general security till 9 May 1793, and the search which was then to be made for him at the Café Anglais, Palais Royal, was evidently ineffectual. One of Monro's latest items of information was the arrival of Sampson Perry, of whom we shall hear more in connexion with Choppin.

The club was dissolved after a prorm discussion in February 1793, bat some further light is thrown on the Engligh gatherings at White's by a long denunciation made to the Place Vendome section on 8 March 1794 by Arthar, a member of the commane, of English extraction, who seems to heve made it his business to play the spy on British residents. Arthur depicted Stone as a man pretending sympathy with the Revolution, but intimate with Brissot and Pétion, and especially with General Mirands. He was also intimate with Milnes, whom the intercepted Lille letters had shown to be an agent of Pitt's. ${ }^{9}$ Stone was also intimate with Robert

- O. Browning, Daspatehes of Earl Gowor.

- Conway's Lifo of Paire.

- Arch. Nat., A. F. ii.*288.

- Here Arthur seems to havo confused William Miles, who had been in Paris in 1791 , and in 1793 had received a pension of $800 \mathrm{~L}$ for his quari-diplomatic services, vith James Milne, or Mylne, an English mechenioian, who, prior to the Reralation, hed introduced spinning and carding machines, and had received a pension of 300 trances. Thet pension ras confirmed by the Assembly in Angant 1791, end in the previous May it had ordered a competitive trial between his epinning mechine and thet of a fallow Englishman, Philemon Pictord. Tho lattor roceired 3,000 trance for orecting his mechine in a room at the Paris hospital. Milno died at Paris in 180t, his ans continuing the business. He seems to have been allowed a brilding at the royal shootiog-box of Le Mratte for his tactory, for on 20 Feb. 1793 he eddrestod a complaint respecting this to the Conrention, which, hovever, declined to consider it. He hed probsbly been onsted trom Is Muette. The Iillo letters, which really seem to have beo the lost property of an English spy, said : 'Milno's plens are approved of 
Smith [Si- Robert Smyth], now arrested. Milnes gave dinners and balls nearly all the week at White's, a kind of English tavern in the Passage des Petits-Peres, now called Hòtel Philadelphie. At one of these orgies [sic] a dispute arose between Thomas Paine and another Englishman, who struck Paine in the face, but after eseaping and being for some time in concealment had become reconciled with Paine. Stone kept his carriage before the Revolution, but had now opened a printing office, and had claimed his wife's release, as being himself a compositor (artisens were exempt from arrest). Stone, however, was about to divorce her, and doubtless intended to marry again. She had brought him $600 l$. or 800l. Gamble, the engraver, was co-proprietor with White, having been surety for him. ${ }^{10}$

The Place Vendome section committee not only entered this long statement, which I have summarised, on its minates, bat ordered a copy to be sent to the committee of general security. It is obviously a mixture of fact and fiction. Paine's assailant was Captain John Grimston, R.A., for Sherwin in his 'Life of Paine' states that Grimston, at an hotel dinner, strack Paine, and might have been punished with death, but that Paine procured him a passport and paid for his journey back to England. These last details require confirmation, but we see that the quarrel was made up, and the records of the committee of general security show that Grimston, who ras living with a Captain Bingham at St. Germain, was summoned to appear before it on $9 \mathrm{Mray} 1793$, and on the 16th was ordered to quit Paris within seren and France mithin fourteen days. He was to hare a passport for any destination he might choose." Some of Arthur's gossip was thus ten months old. The hotel-keeper White was arrested on 9 Hay 1793, probably on account of the Grimston affair. A Christopher White, manufacturer, aged 20, imprisoned from October 1793 to November 1794, may have been his son, and Anna Gray, wifo of White, aged 43, incarcerated during the same period with her tro daughters, 16 and 14 , was probably bis wife.

In tracing the antecedents and subsequent careers of the members of the deputation the alphabetical order will be most convenient, for the sigaatures to the address show no arrangement of any kind, but I may make an exception for two men, so well known that little need be said of them-William Francis Jackson and Lord Edward Fitzgerald. Mfonro, strangely enough, does not mention Jackson, whose name heads the second page of signatures, yet he can scarcely have been any other than the Rev. William Jackson, ex-factotum to the notorions Duchess of

by Pit, bat his late fever will keep him in Englend some time longer.' This posaibly refers to William Afiles, whose bimoirs were pablished in 1891.

1. dreh. Nat., F. 7, 2475, p. 137.

"Ibid. d. F. i..* 288. 
Kingston, who, originally clerk at a Moravian chapel in London, ${ }^{12}$ went to Oxford, but did not graduate, was curate at St. Mary-leStrend, wrote for or edited the Public Ledger, Morning Post, and Whitehall Evening Post, was a prisoner for debt in the King's Bench, and ultimstely poisoned himself at Dublin in order to aroid execution for high treason. It is true that this Jackson is nowhere credited with a second Christian name, but there can scarcely have been two William Jacksons in Paris, both Jacobins to boot. He must also have been the Jackson who, along with a Frenchman named Garnier, had on 11 May 1792 submitted to the Assembly a scheme for obtaining news in twentyfour hours from the most distant frontier. This apparently anticipated Chappe's invention of semaphore signals, bat the Assembly declined to entertain it. In August 1793 he obtained exemption from the general arrest of British subjects, as being in the employ of the French government. Jackson's mission to Ireland in 1795, his misplaced confidence in Cocksyne, a London attorney, his conviction, and his suicide in the dock to s87e his family from the confiscation of his small property are well known.13 His acquaintance with Paine at White's Hotel lends additionel pathos to the employment of his prison hours in writing an answer to the 'Age of Reason.' Paine, indeed, had then told him that he was writing a book against all revesled religion as. nothing bat nonsense and imposture.

It is needless to summarise the career of 80 well known a man as Lord Edward Fitzgerald. It is enough to spests of his brief risit to Paris. He arrived on 26 Oct. 1792, and gave his address as lo citoyen Edouard Fitzgerald, Hotel de White, Passage des PetitsPeres, près du Palais Royal. 'I lodge,' he wrote to his mother, the Duchess of Leinster, 'with my friend Paine; wo breakfast, dine, and sup together. . . . I I pess my time very quietly; read, walk, and go quietly to the play. . . . I go a good deal to the Assembly.' A sabsequent letter, undated, says, 'I dine to-day with Madame Sillery.' According to the latter, better known as Madame de Genlis, Fitzgerald, at a performance of Kreutzer's Italian opera ' Lodoiska,' was struck by a face closely resembling that of Sheridan's rocently deceased wife, of whom he had been enamoured. He found that this was the famous Pamels, the repated daughter of the Dake of Orleans and Madame de Genlis, but more probsbly, as has been ascertained of late years, the offspring of a Newfoundland fisherman's daughter named Sims." He got Stone, who was also at the thestre, to introduce him. Now 'Lodoisks,' which was brought out in 1791,

11 Andrews, Hwitory of Britioh Joumaliom.

Is Soe Dict of National Biography, rix. 110, 111 ; and Fitrpatrick's Secrot Sor. vice under Pilt.

is Dich of National Biography, xix 142,148; Lociamy, 1898. 
had had a run of more than fifty nights, was revived on 1 Nov. 1792, and repeated on 20 December. If Mradame de Genlis' account is to be relied on, Fitzgerald's introdaction to Pamela must have taken place on 1 November. But this woald not agree with ber statement that on her leaving Paris with Pamela for Tournay, two or three days afterwards, he joined them at the first post, that they reached Tournsy in the beginning of December, and that three weeks after he married Pamela. Madame de Genlis' stay in Paris was extremely short, for she was subject to arrest as an émigrée. She could not have been there on 1 Nor. 'Lodoiska,' therefore, could not have been the piece at which the introduction occurred. This is not a material point. Mradame de Genlis is less excusably inaccurate when she asserts that she would not give Fitzgerald her adoptive daughter's hand till be bad obtained his mother's consent, that he accordingly went orer to England to obtain this, and that he returned in a fer days. Fitzgerald's letter to his mother, written on arriving in London with his bride on 2 Jan. 1793, implies that the duchess's consent, or rather recognition, had only that day been given. It is clear that Fitz. gerald had not gone to London to obtain her previous consent, but had married on 27 December either without asking consent or without waiting for the answer. ${ }^{\text {is }}$ As to the British dinner, the London newspapers represented Lord Edward Fitzgerald and Sir Robert Smyth as having there renounced their titles, one of the toasts being 'the abolition of all hereditary titles.' This led to Fitzgerald being cashiered from the army.

Of Thomas Armfield, ${ }^{16}$ Matthew Bellewes, B. Balmer, and John Bradley nothing is known. Bulmer may hare been the father of a well-known printer, William Bulmer. I pass on to Willian Choppin, who became curiously mixed up in the trisl of Marat. Born in 1764, full of enthusiasm for the Revolution, he seems to have migrated with Paine from White's Hotel to lodgings in the Faubourg St.-Denis. There, at any rate, they were fellow-lodgers in April 1793, together with Johnson, a young surgeon from Derby, who had accompanied Redhead Yorke to Paris. Johnson stabbed himself twice with a knife, and announced to Choppin from the top of the stairs that he had killed himself. As though dying he gare Paine his watch and drew up a will dividing his personal effects between Paine and Choppin. This will contained the following passage: 'I came to France to enjoy liberty, but Marat has murdered it. I cannot endure the grievous spectacle of the triumph of imbecility

u The dao de Chertres, the faturo King Louis-Philippe, was present, and signed the register.

16 $\triangle$ Sophin Armfiald, baried at Montmertre cemetery in 1810 at the afe of 92, hed apparently a brother, for she is described as a 'datiful deughter, good sister, and sincere trienda' 
and inhumanity over talent and virtue.' Paine, moreover, gare Brissot, for publication in his Patriote Français, a paragraph drawn up by Johnson himself to the effect that an Englishman, abjuring his country from detestation of kings, but heartbroken to find in France the hideous mask of anarchy, bad resolved on suicide, and before dying had written these words. Jobnson was really alive and well, and is said to have been annoyed at the appearance of the paragraph, bat he had himself indited it and had begon the mystification. ${ }^{17}$ Marat's trial came on just at this time, and the perfectly irrelevant question of this sham suicide was dragged into it. Paine, Choppin, Johnson, and Sampson Perry were called as witnesses. ${ }^{10}$ Perry, in an unpublished letter to a Madsme Lavit, ${ }^{19}$ might well say : 'On the whole it is a mysterious affair, and ought to be cleared up. Some people regard it as a farce, others 88 a tragedy.' Choppin and Johnson leit Paris for Switzerland in November 1793, just in time to escape detention. ${ }^{20}$ They wrote from Bâle to Paine, as he informed Lady Smyth, ' highly pleased with their escape from France, into which they hod entered with an enthusiasm of patriotic devotion.' Two days afterwards a guard arrived at night to arrest them. This was apparently in September or October 1793, when all the English were seized as hostages for Toulon.

Cesar Colclough, eldest son of Verey Colclough, of Tintern Abbey, county Wexford (commonly called Sir Vesey, as heir male of the last baronet, though the title did not descend to him), was born in 1766. His mother was Catherine, daughter of John Grogan, of Johnstown, Wexford. Vesey was high sheriff of Wexford in 1767, and M.P. for that county from 1769 till his death in 1794. Cesar wrs imprisoned at Paris with the other British subjects. He amused himself with carpentry, and taking back that taste with him to Ireland on his release, he made a part of Tintern Abbey his workshop. Many of his tools remained there long after his desth. During his residence in France his youngor brother John represented Wexford, and in 1807 stood for re-election, nominating Sheridan as his collesgue, in opposition to the other outgoing member, Alcock. On the morning of the election there rias a duel between Colclongh and Alcock, in which the former was killed. Alcock, who was elected, was put on trial, but was acquitted. The legend runs that remorse made him insane, ${ }^{21}$ but of this I find no confirmation. This tragic

\footnotetext{
17 Johnson's own eccount was that be was excited by the fear that Paine roold lose his life tor his rote in tarour of Louis XVI.

11 Monitour, $8 \mathrm{May}, 1793$; Arch Nat, W. 260. Paine, anlike his three fellowcountrymen, had to be examined through two interpreters, and knowing, perhepe, that he rould be a witness, he had not roted in the Convention on the prosecution.

10 Arch Nat, W. 269.

= Conway, Life of Paine.

I Berrington, Peronal Sketches.
} 
event probably led to or hastened Cesar's return to look after tbe embarrassed estate left by his extraragant brother. In 1818 he became himself MI.P. for Wesford, and in the same year married Jane Stratford, daughter of Joln Liirwan, barrister. He died at Cheitenham in 1842, leaving no issae. He was buried at Tintern Abbey, and his ridorr erected a monument to his memory in Tintern parish church." The estate then derolred on Nary Grey Wentworth, daughter of another Cesar Colclough, chief justice of Nerfforndland; she married in 1818 John Thomas Rossborough, who took the name of Colclough.

Passing over Jeremie Curtayn, we come to William Duckett, who, born at Killarney in 1768 , was perhaps taken to the Paris meetings by MlacSheehy, his fellow-student of the Irish college. He gained a scholarship at St. Barbe College, and returning to Ireland wrote flaming articles in the Northern Star, under the signature of Junius Redivirus, till prodence dictated, in or before 1796, a flight back to Paris. There he ras busy in inciting a French landing in Ireland, but Tone had an invincible distrust of him, and prevented his embarking in Hoche's expedition. Tone thus rendered Duckett an unconscious service. In 1797 he was secretary to Leonard Bourdon, ex-schoolmaster and Jacobin deputy. In 1798 Duckett was reported to Castlereagh as at Hambarg and entrusted with money for procuring a muting in the English fleet or for burning English dockyards. He was consequently scheduled in the Irish Outlawry Act. Returning to Paris with a Danish wife about 1803 , he became a professor at his resuscitated old college of St. Barbe, and Duruzoir, a pupil, speaks admiringly of his ronderfal memory, his classical attainments - Horace was his favourite author - and his lectures on Shakespeare and MFilton. He also wrote verses on topics of the day, and compiled an English grammar for French students. He died in 1841."

Edward Ferris may have been the disbarred attorney and in. former against the United Irishmen who receired frequent payments out of secret serrice money. ${ }^{21}$ He may also have been related to Richard Ferris, of the Irish college, Paris, seminarist, priest, soldier, and married man, whose singular career ended in $1828.0^{25}$. But this is mere conjectare.

John Frost, a native of Winchester, brought up as a solicitor, and described as 'an attorney of electioneering memory,' became in 1782, at the age of thirty-two, a member of the Thatched House tarern society in London, a body adrocating parliamentary reform. In $\mathbf{1 7 9 2}$ he is said to have sheltered political offenders.

" Information kindly furnished by Mrs. Biddalph Colclough, of Tintern Abbey.

I Dict. of National Biograpky, rri. 92.

:I Fitzpatrick's Secret Sercice Urder Pitt.

$\Rightarrow$ See my Englishmen in the French Rerolution, p. 167. 
He accompanied Paine to Paris in September 1792, when they were rudely searched at Dover. ${ }^{25}$ One of the founders and the secretary of the Corresponding Society, he paid Barlow's expenses to Paris, as rell as his own, on their being depated to present the address. Barke denounced him as an ambassedor to Louis XVI's murderers. Stone, in a letter of 26 Nor. to his brother William, produced at the trial of the latter, mentioned Frost's arrival. Monro on 17 Dec. 1793 writes :

M1r. Frost has left this house [White's], and seldom makes his appear. ance. He is, however, one of the society. He appears, however, a good desl alarmed at his situation, as he told me a reward was offered for apprehending him.

Before leaving London with the address, Frost, at the Percy coffee-house, had declaimed in farour of equality and against monarchy. A man named Batler took him by the nose and kicked him out. As Frost had been dining and was 'probably drunk,' 27 this would seem to have been sufficient punishment; bat on his return to London in February 1793 he was arrested for seditions talk, was ineffectually defended by Erskine, and was sentenced to six months' imprisonment, and exposure in the pillory at Charing Cross. He was also struck off the roll of attorneys, and required on the expiration of his sentence to give sureties for five years for good beharionr. On his release the mob unharnessed the horses of his carriage and dragged him home in triumph. In 1794 the report of the parliamentary committee on sedition referred to his French mission, and he was imprisoned in the Tower with Horne Tooke and other members of the Corresponding Society, ${ }^{20}$ but the prosecution against him was abandoned on the acquittal of the first batch of prisoners. In 1802 he was an unsaccessfal candidate for East Grinstead. In 1813 he received a royal pardon, and applied for reinstatement on the roll of attorneys, bat this the King's Bench refused. Tranquil for the rest of his long life, Frost expired in 1842.2 His Chartist namesake of 1839 was not his kinsman.

James Gamble was a paper-maker and engraver, and occupied part of the premises of Arthur and Robert, at the boulevard corner of the Rue Louis-le-Grand, or Rue des Piques. We have seen how treacherously Arthur profited by the intimacy thas established. An English clergyman (William Jackson ?) who advertised lessons in English in 1791, gave Gamble as a referee..30 Maria Gamble,

* Dropmor MSS. (Hist. MS8. Commission), ii. 816.

7 Dropmore MSS. ii. 940.

- Ses Tooko's Diery, Notes and Quories, Jannary and Febranry 1897.

- [At Holly Lodge, near Lymington, as stated in the Dict. of Nat. Biog, I remember him there as a rery old man, living with an elderly derghter and a bittlo granddenghter. He had taken the rame of Bassell, to koep bis past out of sightB. B. G.]

- Petites Affichea, 1791. 
governess to the children of Joles Didot the printer, and eventually Didot's second wife, was probably his sister. A Paris newspeper of 1790 described Gamble as the inventor of coloured engravings. On 22 Mfay of the previous year he had been licensed to publish a collection of engravings.31 Later on, with a partner named Coypel or Coipel, he engraved rerolatiouary scenes and allegories, and on 18 Jan. 1795 they presented to the Convention a sketch of Brutus condemning his son to death. They asked permission to bay a sheet of copper from the State in order to engrave it. The application was referred to the education committee. ${ }^{32}$ After this nothing more is heard of Gamble, but in 1801 and 1803 a John Gamble of Leicester Square, London, perhaps a brother of James, took out patents for 'making paper in a continuous sheet.'

I pass over Grstinean, Gibson,"3 Green, Hickson, Joyce, and Lower, except to say that Nicholas Hickson, a teacher of languages, was imprisoned at the Scotch College and the Luxembourg from October 1793 to Norember 1795; and that Joyce was probably, to judge from their common sympathy with the Revolution, of the same family as Jeremiah Joyce, Unitarian minister and schoolbook compiler, who was prosecuted for treason in 1794. Nicholes Joyce, a cotton-spinner, who died a prisoner at the Benedictine convent in February 1794, may have been his brother.

Thomas MacDermott was probably the Irish militia colonel who was arrested by the Temple section on 4 Nay 1794. There was, however, another Thomas MacDermott, an Irish priest, who had been chaplain to the French embassy at London. This MacDermott was-arrested at Nancy in Jane 1793, and sent a protest to the Convention." Among his papers 's was a draft letter to his brother, a Dublin lawyer, asking bim, as his heir, to provide for one Mrargaret Noel in return for her services to himself. He seems to have died in Paris after the Terror.

Of Macdonnel, who, like Frost, opposed the second address to the Convention, all we know is that, according to Monro, he wrote for the Morning Post.

Bernard MacSheehy, probably a kinsman of John Baptist MacSheehy, court physician, was born in Ireland on 2 Dec. 1774. He was in 1793 a stadent at the Irish college. On 4 Mray 1794 the committee of public safety appointed him an interpreter on the staff of General Félix for the projected expedition to the East Indies. On 17 March 1798 he was appointed on the staff of the armese d'Angleterre, and in 1803 be was commissioned to organise the

st Tuetey, Repertoire Bist. Paris, ii, 376.

n Proces-Perbaur de la Conrention.

a There was a Gibson in business in Paris in 1708.

"Arel Nab, A. F. iil. 67.

म Ioid. T. 1651 
Irish regiment at Brest. The expedition to England or Ireland came to nothing, and on 8 Feb. 1807 MacSheehy, who had risen to be general, lost his life in the battle of Eylan.35 John Bernard MacSheehy, who entered the French army in 1802, and in 1817 was on half-pay, was probably his son.

Nicholas Madgett was a native of Kinsale, and had probably been a student at the Irish college. He held a benefice near Bordeaur, but from 1784 to 1788 he was chaplain to James Fanning, an Irishman who had purchased the chatean of Roche-Talbot, near Seble.e. In May 1795 he revisited France, landing with a passport under the name of Hurst. He was consequently as a suspected spy imprisoned for six months. He was intimate with Tone, and when the expedition to Ireland was being prepared was despatched to Orleans to prevail on Irish prisoners there to join in it. This caused a quarrel between the English and the Irish prisoners, and the transfer of the English to Valenciennes. Madgett in 1796 advertised himself as a teacher of languages and mathematics. He was employed by the Directory in drawing up reports on English matters, and in translating from English newrpapers. 38 In the 'Castlereagh Memoirs' he is described, under date 1798, as having spent forty of his sirty years in France, and as intimste with Thomas Muir, the Scottish refugee. He suggested the seizare in the Bank of Venice of 10,000,000l. belonging, as be said, to George III, and this suggestion was transmitted by the Directory to Bonaparte, who, however, found no such deposit. In 1811 he is described in the 'Paris Directory ' as interpreter to the Ministry of Marine.

Thomas Marshall, born in 1755, a native of Bentham, Yorkshire, was apparently in business in Paris, for in 1795 he obtained from the committee of public safety a passport arailable for three months for Denmark for private affairs. He seems to have been intimate with Rayment, for on 8 Sept. 1793 they presented a memorial to the Convention respecting a contemplated loan by the Observatory section for the equipment of soldiers for Vendée. The memorial was referred to the finance committee.

Louis Masquerier, the descendant of Huguenot refugees, was a goldsmith in Coventry Street, London, who had become bankrapt in 1777, and had since 1789 been dependent on his wife and daughter, who taught English in Paris. This is all we know of bim, but of his third and youngest son, John James, the portrait painter, much might be said. The boy hod accompanied his mother and sister to Paris, and at the age of fourteen was studying art under François André Vincent at the Royal Academy when, on

* Archices du Dept de la Guerre.

- Beanchesne, Chatear de Roche-Talbat.

2* Areh. Nat., A. F. iii. 57-68. 
10 Ang. 1792, the master dismissed his pupils, saying ' This is no place for you.' Young Masquerier on his way home saw a soldier shot just in front of him, and had to leap over the dead body. In the autamn of 1793-his father had apparently died-be obtained a pessport for England, but his mother, Marie Françoise, and sister, Marie, were imprisoned at the Laxembourg from 10 Oct. 1793 to 26 Oct. 1794, and on their release resumed teaching. In 1802 he revisited Paris, was enabled through Madame Tallien to sketch Napoleon unobserved from a closet, and, using this sketch for a picture of him reviewing the consular guard, made 1,000l. by the exhibition of it in London. In 1814 he fetched his mother and sister back to London, and in 1850, in company with Crabb Robinson, he once more saw Paris. Five years later be died.9 - More a Frenchman in speech and intimate bnowledge of the country than any other friend of mine,' says Robinson, while the poet Campbell describes him as 'a pleasant little fellow with French riracity.'

William Mraxwell was a doctor, but I can discover nothing of his parentage or early life. He may have been the William Maxwell of Carriden, Linlithgowshire, born in 1766, who entered Christchurch, Orford, in 1781 and graduated M.A. in 1791. On 12 Sept. 1792 be convened by advertisement a meeting at his house in Portlend Street, London, to open a subscription for presenting arms to the French, bat four hours before the time appointed the Colonel Glover notorious in connexion with the Duchess of Kingston weut to him and frightened him into abandoning the plan, remoring his door-plate, and absenting himself. Glover posted himself in the house opposite to see what would ensue. Horne Tooke was one of the arrivals, and after obliging Glover to decamp he conducted the people to his own house in Soho Square, where the meeting was held and the subscription opened. 'Marmell's courage was unequal to the occasion,' said Oswald at the Jacobin club on the 30th, in relating, on the authority of Paine and Frost, what had passed."0 Maswell, as we have seen, went over to Paris, and, according to Monro, joined the French army in December 1792. He was in Louis XVI's escort to the scaffold, and gave a minate account of the execution to Oelsner, a German. Though deroid of sympathy for the king, he was amazed at the composure with which Louis entered the carriage, as if for an ordinary drire, gazed at the objects which he passed, and helped the executioner to remore his overcoat and jacket, for which a kind of blouse, almost pinioning his arms, was substituted.

Of Robert Merry, versifier, dramatist, Dellacruscan, friend of

- Moniterr, 25 Sept. 1792; Anlard's Club des Jacobinss. 
Godwin, who visited him in Norfolk," it is needless to spesk at length. Well known in his day, he is all bat forgotten now. He had risited Paris in 1790, and had doubtless witnessed the Federation, for a letter in the Journal de la Société de 1789, for August 1790 , в8ув :

We have here the two best poets in England, both of them philosophers, repablicans, and friends of the Revolution. One of them, Mr. Merry, is at work on a poem celebrating the French Rovolution; it is already far advanced, and will be finished, as he belieres, about December 12 ... The other, Mr. Hayley, in no way yields to his rival.

Merry married in 1791 Elizabeth Brunton, a famous actress, and the daughter and sister of actors. He was president, as we have seen, of the club at White's Hotel, and he remained in France till May 1793, when, apparently having been detained at Calais, the committee of general safety ordered that municipality to grant him a passport, his wife and two servants accompanying him."s In 1796 Merry and his wife went to America, where the latter appeared on the stage. Cobbett, Friting to Gifford in 1797, 14 states that Merry arrived fall of enthusiasm for American liberty, but was soon disenchanted, and speedily fell into obscurity. He died at Baltimore in 1798. He was a count of the Holy Roman Empire, having purchased that distinction for ten guineas. 15

Passing over Mowatt and Murray, the former of whom had trial of three Paris prisons, we come to William Newton (perhaps the William Newton of Longdon, Deron, who entered Oriel College, Oxford, in 1780), a soldier of fortane who, though only thirty years of age, had served not only in the English dragoons but in the Russian army. ${ }^{* 6}$ Offering his sword to the Convention, he was appointed cavalry captain at the military school and joined the French dragoons. On 5 March 1793 he was denonnced to the committee of general security, which ordered his dismissal from the army." He nevertheless, in the following August, contracted to supply baggage wagons of a new model, and this contract was about to operate when the arrest of English residents was decreed. The minister of the interior suggested to the public safety committee that he should be exempted, bat he was nevertheless arrested and confined at the Luxembourg and the Benedictine monastery from October 1793 to June 1794. He was then tried and executed. He is said to have exclaimed in prison, on reading Barrère's report on the crimes of the English government, 'Has Barrère travelled,

"C. Kegan Pad's Life of Goducir.

4 It appeared as an ode for $14 \mathrm{July} 1701$, and ras reciled at the Irondon celebration.

- Arch Nat, A. F. ii. 288.

s Early Lifo of Samusl Rogers.

"Bfemoirs of John Mearraty.

17 Toid, A. F. ii. 288 .

t Arch. Nat, T. 1658. 
then, in England? What crimes can it have committed ?' and he tore up the paper. He is said also to have compared Robespierre to oriental despots, and to have defiantly told the mob round the gaillotine, 'I am happier than your tyrants, for they tremble, whereas I am quite composed.'

Of John Oswald much might be said, were it not sufficient to refer to the 'Dictionary of National Biography' and to the 'Rovolution Française' of June 1897. Sceptic, vegetarian, opponent of wigs and cravats, officer in the Indisn army, traveller among Kurds and Turcomans, versifier, pamphleteer, this son of an Edinburgh coffeehouso-keeper played many parts; but I must confine myself to his career in France. On 11 Sept. 1790 he presented the National Assembly with an ode on the "Triumph of Freedom,' from which it may be inferred that he bad witnessed the Federation of July 14, 1790. He interested himself in the mission to the Jacobin clab of Watt and Cooper as representatives of a Mancliester society. Robespierre had introduced these two delegates to the club, but seems afterwards to have objected to their request for the affiliation of their society. On 27 May, and again on 10 June, 1792, Oswald adrceated the despatch of an address of sympathy to Manchester. He repeated his efforts on 22 Aug. and 30 Sept., and at length on 3 Oct. an address was sent. If, as Southey asserts, there was an altercation at the clab between Robespierre and the Manchester deputation, it ras probably Oswald, not the stripling Watt, who bore the brunt of it. In his speech of 30 Sept. he denounced George III as tyrannical and sangainary, and as a man who should not have been liberated from a lunatic asylum; and he adrocated a revolution in England as essential to the friendship of the two nations. He translated into English the ' Almanach du Père Gérard,' as also a famous revolutionary production by Collot d'Herbois. A memorial by Lewrins, the Irish refugee, ${ }^{18}$ states that when the Girondins were in power, which was in the autamn of 1792 or spring of 1793 , Paine sent Ostrald to Ireland to offer 20,000 men to assist in securing Irish independence. O3wald, whom Lewins mistakenly styles an American, went to Lord Edward Fitzgerald, but Ireland was not then ripe for a rising. Ostrald mas perhaps the sham Irish quaker mentioned by Dumont 99 as trnvelling in France witl a passport from Proland. In March 1792 he had adrocated the abolition of standing armies and the adoption of the pilie as the only weapon. He was anthorised accordingly to raise a corps of volunteers in Paris, and conducted them to La Vendee. He had sent for trro sons to join him as drummers. Fatber and sons were all billed there, probably by their own battalion, for Oswald was a strict disciplinarian, and consequently unpopular. He had a third child, who may

\footnotetext{
is Arch. Nat., A. F. ir. 1072.

- Sonvenirs sur Jirabeau, enp. 10.
} 
bare been the John Oswald who joined the French army as lieu: tenant in 1799, and in 1817 was on half-pay. Oswald was secretary to the British clab, or Society of Friends of the Rights of the People, till its dissolntion in February 1793.

Of O'Neill, O'Reilly, Potier, and Quaterman nothing is known, except that Potier, probably a Channel-Islander, Tras imprisoned with the other British suljects in 1793-94, and that Quaterman, an Irishman, after a year's captivity, was expelled from France in October 1794.

Robert Rayment was an economist who published in 1790 a treatise on the British corn trade, and in 1791 a mork on British national income and expenditure. He was in Paris in August 1792, and presented the latter book to the Assembly. A few days later he reappeared at the bar of that body in company with Gamble, James Watt, jun., and W. Arnviside to offer 1,315 francs for the widows and orphans of the captors of the Tuileries. He becameconnected with the Caisse d'Escompte, but on 19 Oct. 1795 ras arrested with the other English by the Lepelletier section,,$^{50}$ and was incarcerated at the Scotch college and the Luxembourg till 2 Jan. 1795.".

William Ricketts had been in the English navy, and on 28 Dec. 1792 he requested French citizenship and the permission of the Conrention to equip a ressel for the French nary at his own expense and under his own command.st The application Fas referred to the navy committee, and nothing more is heard of it. On 8 Sept. 1793, in concert with Marshall, he Trote, as we have seen, a letter to the Convention respecting a loan contemplated by the Observatory section for the equipment of volunteers for La Vendée. Was he the navy Captain Ricketts who in 1802 married in England a Miss Gumbleton, an IrishFoman?

Rose, who signed without his Christian name, was possibly the Jacques Auguste Rose, of Scottish extraction, to whose care Stone had his letters addressed. He was one of the ushers to the National Assembly and the Conrention, had Robespierre in his charge on the 9th Thermidor, and intrepidly carried a summons to the rebellions commune. He was more probably, however, the Rose who, with Prince, Hodges, and Millin, obtrined on 13 May 1793 an order from the general security committee to grant them passports. ${ }^{33}$ A James Rose was scheduled in the Irish Banishment Act of 1798 .

Stephen Sayre, probably the senior member of the deputation, $\pi a s$ born in Long Island in 1724. In 1766, when living at Philadelphia, be prote a letter on colonial grierances to Lord

so Arch Nat., F. 7, 2478.

a Registre Labat, Prffecture de Police.

* Froces- Ferbaux de la Conecntion.

s Arch. Nat., \& F. ii.* 888 . 
Dartmouth, secretary of state for American affairs, Cowper's model peer, 'who wears a coronet and prays.' In 1772, when be had become a banker in Loindon, he wrote again, adrocsting a board of trade to be elected by the American colonies."4 In 1773 he was sheriff of Liondon and Middlesex. In 1775 he was arrested on the information of adjutant Francis Richardson, a fellow-Ameri. can, who alleged that he had talked of kidnapping the king at the opening of parlisment, and of overturning the government. $\mathrm{He}$ was for five days in the Tower, but was then released on bail. The prosecution collapsing, Sayre sued Lord Rochford, secretary of state, for false imprisonment. He obtained a verdict for $1,000 l$. damages, subject to points of law, eventually decided against him. Meanwhile he had become bankrupt (1776), and had married the deaghter of the Hon. William Noel.ss In 1777 he went to Berlin as an American envoy with Arthur Lee, taking the place at the last moment of Carmichael. Hugh Elliott, the English ambassador, with an andacity for which he was officially rebuked but privately complimented, stole the papers of Lee and Sayre, and after taking copies returned them. ${ }^{36}$ Lord Suffolk, secretary of state for foreign affairs, in a despatch announcing Sayre's departare for Berlin, described him as

a man of desperate intentions, with the disposition rather than the talents to be mischierous. His personal ranity is at the same time so great that he talks of going afterwards to Petersburg, in order to try the effect of his address and figure at that court.

$\mathrm{He}$ is said, indeed, to have gone thither, as also to Copenhagen and Stockholm, and he was for a time secretary to Franklin. Settling in Paris, probsbly at the beginning of the Revolution, Sayre became a partner with Pereyra and Laborde in a tobacco factory; but in Mray 1792 he started in business on his own account, as witness this advertisement:

Tobaceo of the firzt quality, American manufacture. Mr. Sayre, formerly in partnership with Peregra and Laborde at the Bonnet de la Liberté, Rue St.-Denis, informs the pablic and tobacco retailers that he has established a factory and opened a depót at No. 7 Passage des Petits-Pères, near the Place des Victoires. . . . N.B.-A small quantity of this tobacco of the first quality can render saleable (passable) inferior, adulterated, or insipid (erente) tobacco. ${ }^{37}$

Gorani, one of the foreigners receiving French citizenship in 1792, dedicated to Sayre a revolutionary pamphlet. By 1795 he had retarned to America, was an active opponent of Washington, and

3" Dartmouth Papers (Historical MSS. Commission).

ss Anrual Register, 1775-77.

- Transactions of Royal Historical Society, 1889.

4 Journal de Paris, 25 May 1792.

vOL. InI. -NO. III. 
died in Virginia in 1818. Thas by torns an American and an English citizen, Sayre is unaccountably described in Appleton's 'American Biography' as a 'patriot.' This curious qualification he shares with several other personages. Had he earned it by teaching tobacconists the tricks of the trade? His ex-partner Pereyra was guillotined, along with Cloots, in 1794.

Henry and John Sheares figure so tragically in the United Irishmen's morement ss that it is sufficient to spesk of their visit to France. Redheed Yorke accompanied them to Versailles, when even John, though of extreme opinions-his quiet brother, though nine years his senior, being entirely under his influence-was so delighted with the Petit Trianon that he fell on his knees and. rorved to stab every Frenchman he met if a hair of Marie Antoinette's head were touched.99 The legend that John Sheares was enamoured of Théroigne de Méricourt was contradicted in 1851 by Arthar $O^{\prime}$ Connor, who stated that Sheares had no acquaintance with that heroine. It was John Sheares, according to Yorke, who suggested the address to the Convention, and he was certainly the Sheares who, crossing over to, England in the same packet with young Daniel O'Connell, the future Liberator, then a stannch tory, exultantly exhibited a handkerchief dipped in Louis XVI's blood. The departure of the Sheareses from. Paris had been notified to the English government by Somers, who described them as 'men of desperate designs, capable of setting fire to the dockyards.' ${ }^{60}$

Passing over Skill, we come to Sir Robert Smyth, whose name was so often spelt Smith ${ }^{\text {ol }}$ as to show the identity of prononciation of the two forms. He was a baronet of Berechurch Hall, Essex. He was born in 1744, and was probably the Robert Smyth who entered Trinity College, Cambridge, in 1766 . In 1770 he married the daughter of $\mathrm{Mr}$. Blake of Hanover Square, and the engraving of a picture by Reynolds of 1777 shows Lady Smyth with her three little children, a picturesque group. In 1780 Smyth became M.P. for Colchester, and he retained the seat till 1790. By that time he had probably settled at Paris. In the autumn of 1792 he assisted Lord Wycombe in procaring the escape from Paris of Madame de Flahault, with the manuscript of her tale 'Adèle de Solanges ' ander ler arm. She had kad apartments at the Lourre, where in 1791 Lord Holland and Windham met Talleyrand at her supper parties.62 Lord Wycombe, son of Lord Lansdowne, had been smitten by her charms, and she is said to hare aimed at marrying him. On.

s Madden's United Irishmen; Fitzpatrick's Secret Service under Pilt.

- Yorke's letter to Wickham, 9 Aug. 1798, in Casthereagh Memoirn, i. 258.

- 13rowning's Despatches of Earl Gorcer.

a By Roynolds and Paine among others.

a Ioord Holland's Momoirs of the Whig Party. 
18 Nor. 1793 'Smithe' (sic) was arrested by the Place Vendòme section in Paris, and sent to the Champs-Elysees section with a request to have the law for the detention of British subjects enforced against him. The latter section applied for information to Rochefort, a village near Dourdan (Seine-et-Oise) where Smyth apparently had a country-house. On 23 Nov. he produced letters showing that the committee of general security had ordered his liberation at Dourdan, where he had, it seems, been previously arrested. The Champs-Elysées section thereupon directed that his papers should be exsmined, and nothing suspicious being found in them he was next day released. Having settled, indeed, in Paris before $14 \mathrm{July} 1789$, be was not liable to detention as a hostage for Toulon. Paine during his incarceration corresponded with Lady Smyth, and that in a playful rein which we should scarcely have expected of him.t Sir Robert apparently retarned to England and remained there till the peace of Amiens, when he opened a bank in Paris; but on 12 April 1802 he died of a sudden attack of gout, whether in England or at Paris is not quite clear.s His widow remained in Paris, where in April 1803 her daughter married Lambton Este, son of the Rev. Charles Este. Este had been erroneously supposed by Lord Malmesbury in 1796 to be courting the mother instead of the daughter. Lady Smyth died at Versailles on 4 Feb. 1823. Her son George Henry had succeeded to the baronetcy, which became extinct with him.

John Hurford Stone, the president of the ineeting, born at Tiverton in 1768, was a London coal merchant, and a member of Dr. Price's congregation. He was well acquainted with continental languages and literatures, and his dinner parties included such men as For, Sheridan, the poet Rogers, and Talleyrand, sometimes also Madame de Genlis and her adopted daughter, Pamela. The latter, indeed, was introduced by Stone to her future husband, Lord Edward Fitzgerald. Stone, according to a family tradition, witnessed the capture of the Bastille, bat he did not figure on Cloots's deputation of Jane 1790. He was in Paris, hawerer, in September $1792,{ }^{66}$ and had perhaps remained there till November. He retarned to England in February 1793, along with forty fellowcountrymen unprovided with the passports required by the traitorous correspondence act, and some of them had to stay three days on board off Dover before they were allowed to land. In May Stone was again in Paris, giving evidence in favour of General Miranda. He and his wife, Rachel Coope, were arrested in October 1793 , but soon released. In April 1794, probably on account of

- Arch. Nat., F. 7, 2673-74.

a Conmay's Lifo of Paire.

- Monileur. 6 Floréal, an I.

- See letter from Dland Burges to Irord Aackland, Dropmore MSS. ii. 309. 
Arthur's denunciation, ${ }^{67}$ he was again arrested, but liberated next day, seemingly on condition of quitting France, for he went to Switzerland with Helen Maria Williams. He returned in June and obtained a divorce, thas confirming Arthar's story of his intention to separate from his wife, who had been living with another grass ridow, Joel Barlow's wife. He had started in business as a printer, for England was henceforth closed to him by an indictment for high treason, though his brother William, a co-defendant, was ultimately acquitted. Whether or not secretly married, Stone and Helen Williams lived together, and the connerion was recognised by the lady's friends, for even the quaker abolitionist Clarkson, after visiting her in Paris in 1818 , in writing to her gave 'compliments to Mr. Stone.' Stono was ultimately ruined by undertaking to print a costly edition of Humboldt's 'Travels.' He died in 1818, having been naturalised simultaneously with Helen Williams, who erected a tombstone in Père-Lachaise as 'the last tribute of a long friendship,' and she was laid to rest close by him in 1827 .

Tickell can searcely have been the Rev. John Tickell (1727-1802) who held various English benefices, but may have been of the same family. There was a Francis Treddell, a Northambrian equire, living in 1802, but bere again the identity is uncertain. Walker was probably the man who delivered reform speeches at. Manchester and Sheffield in the autumn of 1792. He may have been the Walker, porcelain manufacturer in Paris, whose son John Walker, \& vendor of elastic braces at Paris in 1800 , took out in England a patent for elastic gloves in 1807. Of Wardell and Watts nothing is known. Webb was probsbly the Webb of King Street, London, who later on gave Teeling, the United Irishman, a letter of introduction to Paine, ${ }^{68}$ and the Joseph Webb to whom in 1799 was attributed the English translation of Holbach's sceptical ' Histoire critique de Jésus-Christ.' There was, however, a youth named Webb, having a French priest as a totor, who in September 1792 obtained the remoral of seals placed on his property as though he had been an emigré.

We have come to the end of the members of the deputation, bat among those present at the first meeting-for we know that they attended the second-were in all probability Johnson, who, we have seen, was a fellow-lodger of Choppin, and his friend Henry Redhead Yorke. They had travelled together from Derby, where Johnson, Yorke assures us, was ' universally respected as a man of honour.' We learn nothing more of him after bis departure from Paris with Choppin. Yorke, who accompanied him from Derby to Paris, trenty years of age, in independent circumstances, and probably a native of Little Eaton, near Derby. 
In this same year 1792 he had published a letter addressed to Bache Heathcote against the abolition of the slave trade, but he speedily changed sides on this and probably on other questions. 'Madly in love,' as he says, ' with ideal liberty,' he ardently sympathised with the French revolution, and he made the acquaintance of Paine, Frost, and, as we have seen, of the brothers Sheares. Nerertheless, both he and Johnson deprecated a French invasion of England, and they negatived by a majority of one a proposal in the British clab to present a second address to the conrention, asking it to 'rescue England from slarery.' $\omega$ The adrocates of the address revived the proposal, whereupon Johnson and Yorke seceded. Oswald, in a rage, told Yorke he was not fit to live in a civilised society. Yorke had taken his pro-slavery pemphlet with him to Paris in order to wrile a refutation of it. On quitting Paris, with the intention of winding up his affairs in England and settling in France with his ' family'-by which term he may hare meant a mother and brother, for he was anmarried-he left this pamphlet in the hands of ' $\mathrm{R}$. ,' ' in the political world'-evidently Rryment. Yorke, who either returned to England ria Holland, or subsequently risited the latter country, was there told by one John Morgan, who had recently left Paris, ${ }^{\text {To }}$ that Rryment went to the committee of general security, and denounced Yorke as an English spy, whose real name was Redhead. Yorke, indeed, had but recently assumed the name by which he was henceforth known. Rayment produced the pamphlet in corroboration of his assertions, and the pamphlet bore the name of Redhead. The committee thereupon issued a warrant for his arrest, seized his effects, and. interrogated several Englishmen as to his whereabouts. This is Morgan's story, which Yorke credited, but I have found no trace of the alleged warrant, nor is it easy to understand why Rayment should denounce Yorke . when quite out of reach. Yorke in 1793 published a letter of sympathy to Frost, then a prisoner in Newgate. He advocated parliamentary reform at Derby and Sheffield, and on 7 April 1794 he addressed an outdoor meeting in the latter town. He was alleged to have boasted in this spuech that though only twenty-two he had assisted the American, Dutch, and French revolutions, and would continue to cause revolutions all over the world. He manifestly could not have shared in the American revolution, for the war of independence terminated when he was but fourteen years of age; but he must have spoken of Holland and France. He was prosecuted for sedition and conspiracy, made an injudicions speech in defence, and was sentenced to two years' imprisonment.

- Seo aboro, p. 676.

- Probsbly the Margan who, son of an Irish M.P., offered while in Paris, nceording to Somers, to arsessinate George III. 
In default of finding sureties for seven years' good behaviour, his imprisonment seems to have lasted nearly four years ; but he had not lacked consolation, for he fell in love with the keeper's daughter, Miss Andrews, whom he married in $1800 .{ }^{n}$ By the time of his release, moreover, his opinions had changed. He became the vindicator of the war with France, and on revisiting Paris in 1802 found Paine equally disillasioned with the Revolution. While engaged in editing and continuing Campbell's 'British Admirals,' be died in 1823.

General Thomas Ward, who served under Dumouriez, also lodged when in Paris at White's, and probably joined the club. He related to Paine that Marat had said to him, "There are about three handred brigands in the Convention; their heads shall fly off.' Paine repeated the saying to the committee of twelve in 1798.22 Ward, a native of Dublin, born in 1746, was among the victims of the alleged Carmelite prison plot in 1794. The indictment charged them with haring procured ropes in order to escape from prison and massacre the Convention. 3

We have seen how the British club, after lasting only a few weeks, was broken up by dissensions, one party loving their native land and regarding it as a model for France, the other viewing the French revolution as a kind of new religion, to be imitated by, and if necessary enforced upon, England. We have seen also what vicissitudes befell its members. Six had violent deaths. Jackson took poison to avoid the gallows; Fitzgerald was killed in resisting arrest ; the two Sheareses were executed; Oswald fell in battle, probably through treachery; Newton perished on the scaffold. A seventh, Ward, may perhaps be added to the list. Ten suffered imprisonment in Paris-Colclough, Macdermott, Madgett, Mowatt, Paine, Potier, Quaterman, Rayment, Smyth, and Stone, not to speak of Sampson Perry, a late-comer, who had experience both of French and English prisons, while two others, Frost and Yorke, underwent incarceration in England. If we had the full roll of inembers, we should probably find additional victims, if not of the guillotine, of the dungeon. The Reign of Terror, even to those who escaped its rigours, must have been a cruel disillusion, and those who lived to witness the despotism of Napoleon must have bewsiled their shattered hopes. 'Do you call this a repablic ?' exclaimed Paine to Yorke when they met again in Paris in 1802 ; ' why they are Forse off than the slaves at Constantinople.' The French revolution must not, it is true, be looked at from this point of view exclusively, but it certainly ranks as the most colossal disappointment-deception as the French would say-in human annals.

J. G. ALGBr.

"Gentleman's Magarino, May 1800.

n Schmidt, Tablearux do la Rovolution, is 252,

Arch Nat, W. 129. 